\title{
Recurrence of SARS-CoV-2 RNA among Positive Covid-19 Cases
}

\author{
Amresh Kumar Singh ${ }^{1}$, Ankur Kumar ${ }^{2}$, Vivek Gaur ${ }^{2}$, Indra Prasad Adhikari ${ }^{3}$, Raj Kishore Singh ${ }^{4}$ \\ ${ }^{7}$ Department of Microbiology, Baba Raghav Das Medical College Gorakhpur, Uttar Pradesh, India \\ ${ }^{2}$ Viral Diagnostic Research Laboratory, Department of Microbiology, Baba Raghav Das Medical College, Gorakhpur, \\ Uttar Pradesh, India \\ ${ }^{3}$ Department of Biochemistry, Baba Raghav Das Medical College, Gorakhpur, Uttar Pradesh, India \\ ${ }^{4}$ Covid-19 Ward, Department of Medicine, Baba Raghav Das Medical College, Gorakhpur, Uttar Pradesh, India
}

\begin{abstract}
Coronavirus disease 2019 (Covid-19) is a highly infectious disease, and its replication decreasing rapidly after the first week, while some level of immunity is built up. A small proportion of discharged patients may become positive again for severe acute respiratory syndrome Coronavirus-2 (SARS-CoV-2) RNA, even if they meet the discharge criteria. Reinfection of SARS-CoV-2 is an apparently uncommon entity and only a few case reports or case series have been reported from across the whole world. Herein, we have reported two rare Covid-19 cases with recurrence of positive SARS-CoV-2 RNA after a complete clinical cure. The first case was redetected with Covid-19 with more severity after a gap of approximately three weeks after cure, and the second case has recurred after approximately seven weeks with a complication of pulmonary thromboembolism. We report here, the first few cases of a more vigorous Covid-19 recurrence with SARS-CoV-2 RNA in India. J Microbiol Infect Dis 2021; 11(2):108-113.
\end{abstract}

Keywords: COVID-19, SARS-CoV-2, RT-PCR, recurrence, Re-infection

\section{INTRODUCTION}

The rapidly spreading Covid-19 pandemic resulted in more than 33.1 million cases diagnosed and 9,98,000 deaths on September $28,2020[1,2]$. Since the first report in December 2019, up to mid-September 2020, the Covid-19 pandemic caused by the Severe Acute Respiratory Syndrome Coronavirus-2 (SARSCoV-2) [2]. Immunity to SARS-CoV-2 involves both cell-mediated and humoral responses, but its protective role from re-infection along with definitive viral clearance is uncertain [3]. A single-center study reported that $7.41 \%$ of Covid-19 patients re-tested positive for SARSCoV-2 RNA by real-time reverse transcriptasepolymerase chain reaction (RT-PCR) test, and this finding has challenged the current hospital discharge criteria for containing the pandemic [4]. However, a still restricted but growing body of publications indicates that certain patients might reactivate a sub-clinical to clinical infection or be re-infected [5]. Hereby, we have described two cases of Covid-19 infection with reinfection/recurrence and the findings of this study provide information for vigilant monitoring and the management of recovered patients with different risk levels/complications.

\section{CASES}

\section{Case 1}

On 12th July 2020, a 56-year-old man residing in Gorakhpur, UP a chronic smoker with wellcontrolled diabetes mellitus for Covid-19 reported fever, headache without respiratory symptoms (Table.1). Two days later $\left(14^{\text {th }}\right.$ July 2020), he developed mild respiratory distress with $\mathrm{SpO}_{2}$ of $94 \%$ at ambient air and in-lieu of Covid-19 infection, respiratory sample was collected (oropharynx and nasopharynx) for SARS-CoV-2 detection by RT-PCR, which targets specific genes for SARS CoV-2; open reading frame 1ab (Orf1ab), RNA dependent RNA polymerase (RdRP), N genes and $\mathrm{E}$ genes. The cycle threshold $(\mathrm{Ct})$ values from the

\footnotetext{
Correspondence: Dr- Amresh Kumar Singh, VRDL (Covid-19 Lab), Department of Microbiology, Baba Raghav Das Medical College Gorakjpur, UP, India

Email: amresh.sgpgi@gmail.com

Received: 21 December 2020 Accepted: 21 April 2021

Copyright (C JMID / Journal of Microbiology and Infectious Diseases 2021, All rights reserved
} 
RT-PCR were measured; Ct values $<40$ were reported as positive as per WHO [6]. The sample tested positive for SARS-CoV-2 RNA by RT-PCR (Table 2). Simultaneously hematological and biochemical investigations were also done on the day of confirmatory diagnosis of Covid-19, which revealed normal hemogram except mild lymphocytosis, and mild thrombocytopenia (Table 3).

In the next follow-up sample collected on 20th July, and the viral RNA was no longer detected in RT-PCR. Being a mild infection, the patient was treated with oral azithromycin, doxycycline plus analgesics, and antipyretics for five days, when symptoms subsided. The serological test was also negative for IgG anti-SARS-CoV-2 by SARS-CoV-2 IgG assay (Abbott, III. USA). However, three weeks later, the symptoms returned more acutely and included high-grade fever, cough, headache, myalgia, arthralgia, anosmia, and fatigue, and lasted for almost two weeks (Table 1). SARS-CoV-2 RNA detection reversed to positive on 3rd September 2020 (Table 2).

The second episode among hematological and biochemical parameters tested, which revealed a more severe infection (Table. 3). These parameters indicated more severe infection/inflammations and remained positive in another RT-PCR testing on 16th September 2020 (Table 2). Chest computed tomography (CT) scan showed typical findings of multiple patchy ground-glass opacities.

During this second episode of Covid-19, the patient was again treated in-lieu of severity with azithromycin, doxycycline, and injectable remdesivir, IL-6 inhibitor (tocilizumab), and methylprednisolone for six days. Finally, on 22nd September 2020, IgG antibodies were detected and viral RNA was negative even on 24th September 2020, with marked radiological improvement, and the patient was discharged in a satisfactory condition (Figure 1). The patient was again called for a routine follow-up checkup, he was asymptomatic with mild weakness and malaise.

\section{Case 2}

On May 11 2020, a 48-year-old man visited the Emergency, BRD Medical College Gorakhpur
UP, India, with fever, cough shortness of breath, and anorexia for 2 days. Physical examination revealed normal vital signs except a high respiratory rate (>30/min), but because of $92 \%$ oxygen saturation on ambient air, the patient was promptly treated with $\mathrm{O}_{2}$. The patient has not revealed any apparent underlying medical condition such as diabetes, hypertension, or cardiovascular disease. The digital chest X-ray showed features of pneumonia. The RT-PCR was collected on May $11^{\text {th }}$, revealed the presence of SARS-CoV-2 RNA (Table 2).

Simultaneously, serological assays revealed the absence of IgG anti-SARS CoV-2. On a routine basis among hematological and biochemical parameters tested, which revealed normal hemogram except marked lymphocytosis (55\%) with thrombocytopenia (Table 3).

Based on the criteria of Wang et al. 2020, the patient had a severe form of the disease due to the presence of fever, respiratory symptoms, radiological signs of pneumonia, and $\mathrm{PaO}_{2} / \mathrm{FiO}_{2}<300 \mathrm{mmHg}$ [7]. The patient was treated with $\mathrm{O}_{2}$ at different volumes (up to 50\% $\mathrm{FiO}_{2}$ ), lopinavir/ritonavir, hydroxychloroquine, and methylprednisolone. In the routine checkup after 6 days, the chest $X$-ray showed a slight radiological improvement, but SARS-CoV-2 virus RNA was again detected. The patient was reassessed on $14^{\text {th }} \& 15^{\text {th }}$ May, a gross clinical improvement (asymptomatic) was noted with negative SARS-CoV-2 virus and discharged on $15^{\text {th }}$ May with $\mathrm{SpO}_{2}$ at $98-99 \%$ in satisfactory condition. The chest X-ray PA view showed only blurred areas of parenchymal thickening. The patient was virologic cured based on negative RT-PCR on June $10^{\text {th }}$.

However, on 05th July, he developed symptoms, i.e., high-grade fever, dyspnea, malaise/fever, and severe chest pain (Table 1). He visited again the Emergency, where he was re-admitted to the same ward with suspicion of "pulmonary thrombo-embolism and or re-infection of Covid19". In-lieu of pulmonary thromboembolism, a High Resonance-CT scan was done, which showed the presence of segmental and subsegmental signs parcel area of ground glass suggesting pulmonary thromboembolism (Figure 2). 


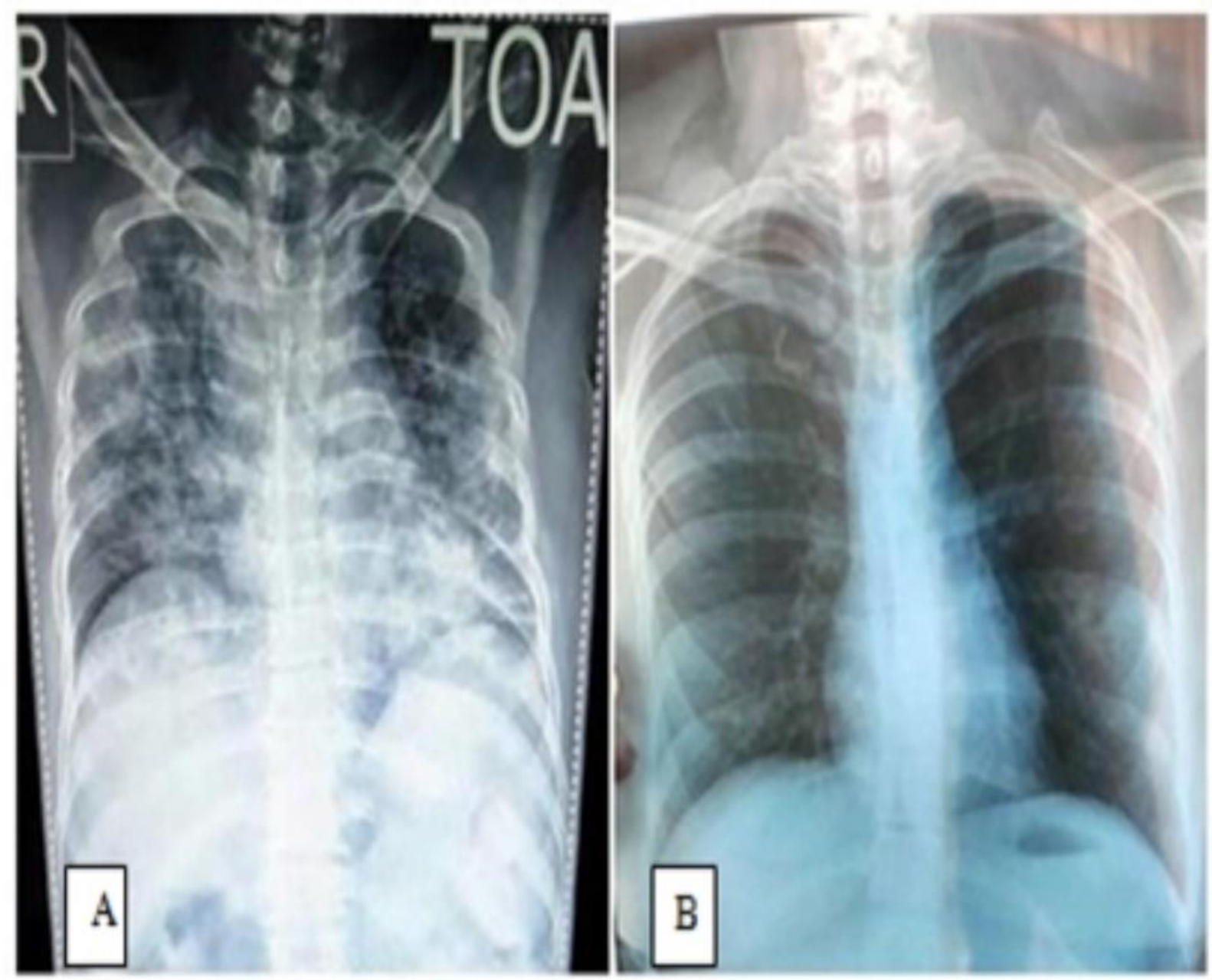

Figure 1. Chest X-rays Images showing.

(A): Spectrum of pure ground glass, mixed ground glass opacities to consolidation in bilateral peripheral middle and lower lung zones (right side lung was more involved than left side);

(B) Marked radiological improvement in ground glass opacities in bilateral side.

Table 1. Clinical features and date of admission with treatment given for both Covid-19 cases during both episodes of infection.

\begin{tabular}{|c|c|c|c|c|c|c|c|c|}
\hline Case & $\begin{array}{c}\text { Date of } \\
\text { positive RT- } \\
\text { PCR }\end{array}$ & $\begin{array}{c}\text { Date of } 1^{\text {st }} \\
\text { negative RT- } \\
\text { PCR }\end{array}$ & - Symptoms & $\begin{array}{c}\text { Date of } 2^{\text {nd }} \\
\text { positive RT- } \\
\text { PCR }\end{array}$ & $\begin{array}{c}\text { Date of } 2^{\text {nd }} \\
\text { negative } \\
\text { RT-PCR }\end{array}$ & $\begin{array}{l}\text { Symptoms of } \\
2^{\text {nd }} \text { infection }\end{array}$ & Treatment & Outcome \\
\hline 1 & 14/07/2020 & $26 / 07 / 2020$ & $\begin{array}{c}\text { Mild } \\
\text { Respiratory } \\
\text { distress, } \\
\text { fever, } \\
\text { anorexia, } \\
\text { headache }\end{array}$ & 02/08/2020 & 22/08/2020 & $\begin{array}{l}\text { Fever, cough, } \\
\text { headache, } \\
\text { myalgia, } \\
\text { arthralgia, } \\
\text { anosmia, } \\
\text { apnea, } \\
\text { fatigue }\end{array}$ & $\begin{array}{l}\text { Azithromycin, } \\
\text { Doxycycline, } \\
\text { Remdesivir } \\
\text { analgesics, } \\
\text { antipyretics, } \\
\text { supportive } \\
\text { management }\end{array}$ & $\begin{array}{c}\text { Survive \& } \\
\text { Healthy }\end{array}$ \\
\hline 2 & 02/05/2020 & $15 / 05 / 2020$ & $\begin{array}{c}\text { Fever, } \\
\text { cough, } \\
\text { shortness of } \\
\text { breath, } \\
\text { hypoxia }\end{array}$ & 05/07/2020 & $16 / 07 / 2020$ & $\begin{array}{c}\text { Dyspnea, } \\
\text { malaise, } \\
\text { fever, severe } \\
\text { chest pain }\end{array}$ & $\begin{array}{c}\mathrm{O}_{2} \text {, lopinavir/ } \\
\text { ritonavir, } \\
\text { HCQS, } \\
\text { prednisolone, } \\
\text { supportive } \\
\text { management }\end{array}$ & $\begin{array}{c}\text { Survive \& } \\
\text { Healthy }\end{array}$ \\
\hline
\end{tabular}


Table 2. CT values of different genes targeted in RT-PCR among both Covid-19 cases during both episodes of infection

\begin{tabular}{lcccccccc}
\hline Case & \multicolumn{1}{c}{ CT Value of ${ }^{\text {st }}$ RT-PCR } & \multicolumn{5}{c}{ CT Value of $2^{\text {nd }}$ RT-PCR } \\
& E gene & N/S gene & ORF1ab & RdRp & E gene & N/S gene & ORF1ab & RdRp \\
Case 1 & 33.5 & 30.8 & 36.1 & 32.3 & 32.8 & 34.5 & 29.7 & 33.4 \\
Case 2 & 16.5 & 20.4 & 19.8 & 18.3 & 25.7 & 31.4 & 29.4 & 28.9 \\
\hline
\end{tabular}

Table 3. Hematological and biochemical parameters of the Covid-19 cases.

\begin{tabular}{|c|c|c|c|c|c|c|c|c|}
\hline \multicolumn{9}{|c|}{ First episode of SARS CoV-2 positive, it's correlation with different hematological \& biochemical parameters } \\
\hline Case & $\begin{array}{l}\mathrm{Hb} \\
(\mathrm{g} / \mathrm{dl})\end{array}$ & $\begin{array}{c}\text { TLC } \\
\text { Cells } / \mathrm{mm}^{3} \\
\end{array}$ & $\begin{array}{c}\text { DLC Cells } / \mathrm{mm}^{3} \& \\
\text { Platelets counts (lacs) }\end{array}$ & $\begin{array}{c}\text { Serum ferritin } \\
(\mathrm{ng} / \mathrm{ml})\end{array}$ & $\begin{array}{l}\mathrm{LDH} \\
\mathrm{u} / \mathrm{L}\end{array}$ & $\begin{array}{c}\text { D-dimmer } \\
(\mathrm{mg} / \mathrm{L})\end{array}$ & $\begin{array}{c}\mathrm{CRP} \\
(\mathrm{mg} / \mathrm{dL})\end{array}$ & $\begin{array}{l}\text { Vit. D } \\
(\mathrm{ng} / \mathrm{ml})\end{array}$ \\
\hline 1 & 12.7 & 4600 & $\begin{array}{l}\text { P43, L48 (High), E03, } \\
\text { M05, B01 } \\
\text { Platelet count-1.1X10 }\end{array}$ & 19.32 & 361.2 & 0.08 & 5.6 & 39.5 \\
\hline 2 & 14.7 & 3460 & $\begin{array}{c}\text { P37 (L), L55 (High), } \\
\text { E05, M03, B00 } \\
\text { Platelet count- } \\
0.76 \times 10^{5} \text { (Low) }\end{array}$ & 454.1 & 473.2 & 7.2 & 92.1 & 10.9 \\
\hline \multicolumn{9}{|c|}{ Second episode of SARS CoV-2 positive, its correlation with different hematological \& biochemical parameters } \\
\hline 1 & 10.2 & 4100 & $\begin{array}{c}\text { P40, L51 (High), E04, } \\
\text { M05, B00 } \\
\text { Platelet count- } \\
0.91 \times 10^{5} \text { (Low) }\end{array}$ & 487.2 & 561.2 & 4.7 & 49.9 & 12.5 \\
\hline 2 & 12.5 & 4460 & $\begin{array}{c}\text { P39 (Low), L51 (High), } \\
\text { E05, M05, B00 } \\
\text { Platelet count- } \\
0.87 \times 10^{5} \text { (Low) }\end{array}$ & 440.1 & 389.8 & 5.7 & 81.3 & 13.2 \\
\hline
\end{tabular}

Hemoglobin $(\mathrm{Hb})$, Total Leukocyte Count (TLC), Differential Leukocyte Count(DLC), C-reactive protein (CRP), lactate dehydrogenase (LDH), Vitamin D (Vit. D), Polymorphs/ Neutrophils (P), Lymphocytes (L), Eosinophils(E), Monocytes (M), Basophils(B)
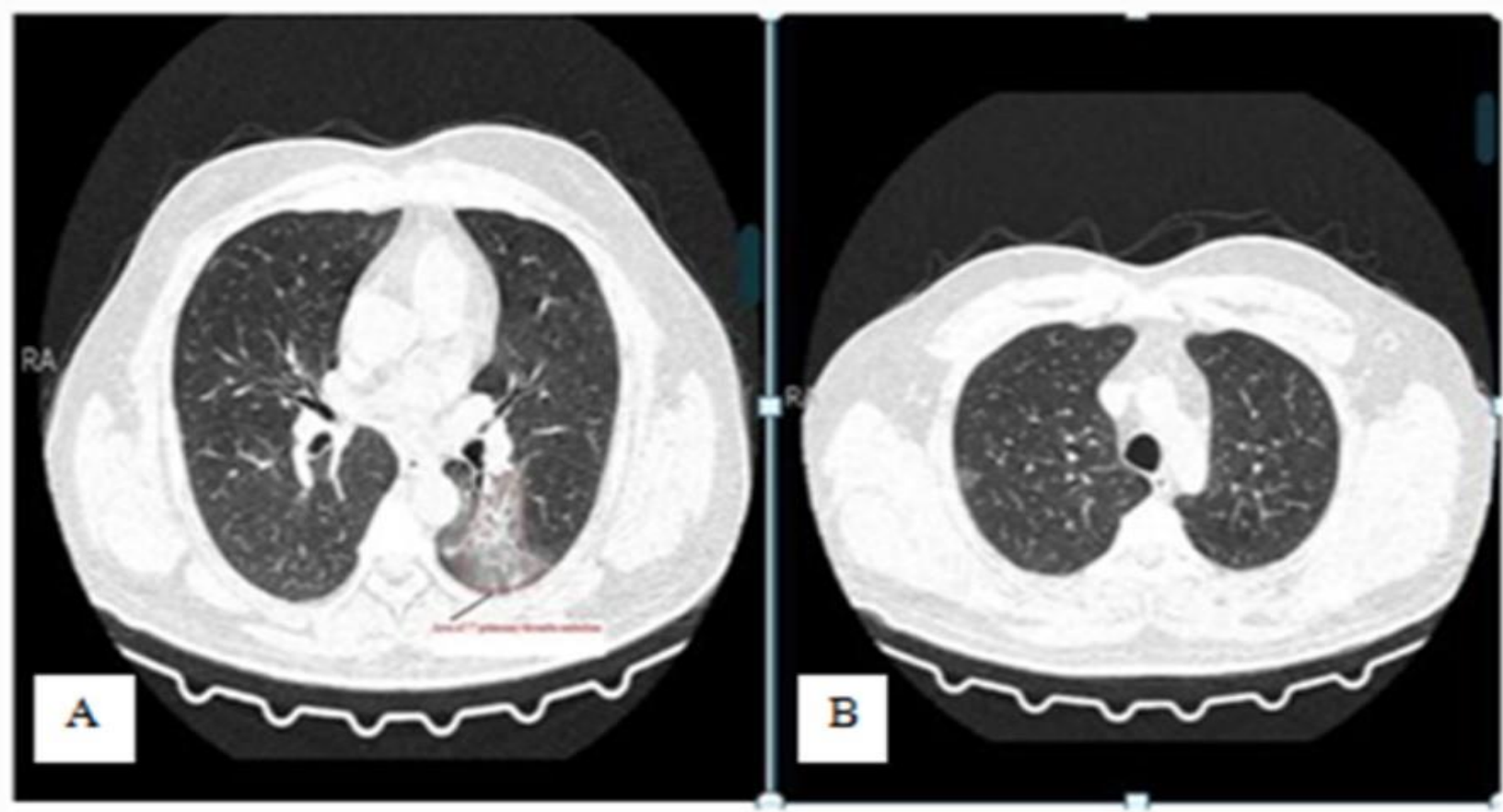

Figure 2. CT images shows (A)- Area of sub-segmental signs of arterial microembolism suggesting pulmonary thromboembolism -(highlighted as red circle) with multiple patchy ground glass opacities (not shown in this image), (B)-Resolution of image after anticoagulation therapy. 
Because of recent clinical history and $\mathrm{SpO}_{2}-$ $88 \%$, a SARS CoV-2 RT-PCR assay was performed and found to be positive with the presence of IgG anti-SARS CoV-2 (Table 2). Taking into consideration of pulmonary thromboembolism, it was planned to give anticoagulant therapy along with ivermectin and O2 supplementation through a high flow nasal cannula next ten days. The patient was discharged in healthy and condition without any symptoms and satisfactory radiological findings with $\mathrm{SpO} 2 \sim 98-99 \%$ at ambient room air.

\section{DISCUSSION}

Worldwide, different reports indicate that reactivation or re-infection by SARS-CoV-2 is possible, although the prevalence is less common [8]. Such "reversal to positivity" after negative RT-PCR test may be due to technical issues such as sample cold-chain problems, poor quality sample collection, etc., pointing towards false-negative results [9].

In the first case, after infection, the patient was clinically recovered, but one chance may be virus was still replicated in undetectable levels in the nasopharynx and in the lower respiratory tract as seen in other reports during convalescence, regaining full replication after some time, probably driven by the host's immunity [10-11]. On the other hand, a reinfection with a new or maybe the same circulating strain is not unfeasible [3], given the different profiles of immune response to the virus [12]. In fact, the detection of SARS-Cov-2 RNA with the absence of anti-SARS-CoV-2 antibody response has been already previously reported [13]. Although cases vary in terms of serological data, the timing of reactivation and clinical presentations among patients who tested positive to SARS-CoV-2 generally have a mild or asymptomatic course [14].

Our second patient, on the other hand, presented a more potent form of Covid-19 after more than 55 days from the first mild infection. Our hypothesis is that the first mild infection was not sufficient to build up a detectable humoral response, which occurred only after 14 days of a second more severe episode [13].

The presence of the virus in infected patients seems to be fluctuant because of the possible occurrence of false-negative results in RTPCR, because of viral load, the experience of the technicians, and the sampling site [15]. Nevertheless, the case we described, points to a real reactivation, since the molecular test became positive again following three previous negative tests in one month. In a recent paper, Ye et al. reported a 9\% proportion of reactivation in Covid-19 patients after discharge [11].

Pre-symptomatic and asymptomatic carriers may be infectious [16]. This case had antiSARS-CoV-2 lgG, indicating that the acute phase of the disease. Preliminary evidence suggests that antibody responses occur in those who have been infected [12]. If these antibodies are protective and how long their protection will last, is yet to be established. According to the present report, we could speculate that in some cases the presence of mildly elevated $\lg G$ antibodies is not protective. In addition, reinfection or false negativity sometimes for the nasopharyngeal tests cannot be ruled out [17].

A limitation of this study is due to the absence of cell culture assays, which could indicate the presence of infectious particles. However, given the 1) high specificity of RT-PCR test; 2) presentation of symptoms coinciding with the positive RT-PCR; and 3) viral detection in close family members living in the same residence during Covid-19 symptoms; such false result is unlikely.

The re-infection with SARS-CoV-2 seems unlikely, taking into consideration on level and duration of of viral neutralizing antibody, duration from past infections, the type of specimen, testing methods used before discharge, and the presence of fecal viral RNA without replication. In this paper, we described Covid-19 recurrence from a mild to a moderate form after convalescence, with RT-PCR turning positive and negative $\lg G$ antibody, even after more severe symptoms. So, there is strong need to study the immune response in different hosts as well as whole genomic surveillance of virus, which may be beneficial to understand the genetic mechanism of re-infection. This case report also highlights the need for the study of immune response in different hosts as well as whole genomic surveillance of agents, which may be potential risk for re-infection.

In conclusion, the ongoing public health emergency requires additional and urgent 
investigations on convalescent cases, to contain the Covid-19 pandemic.

\section{ACKNOWLEDGMENTS}

Written informed consent was obtained from the patient for publication of this case and any accompanying images. All available information is contained within the manuscript.

Declaration of Conflicting Interests: The authors declare that they have no conflict of interest.

Financial Disclosure: No financial support was received.

Ethical Approval: The study was approved by the Baba Raghav Das Medical College Institutional Human Ethical Committee (register IHEC/BRDMCGKP/03/09-2020) registered under the Department of Health Research, Government of India.

\section{REFERENCES}

1) Gousseff $M$, Penot $P$, Gallay L, et al. Clinical recurrences of Covid-19 symptoms after recovery: Viral relapse, reinfection or inflammatory rebound. J Infect 2020; S0163-4453(20):30454-60.

2) World Health Organization. Coronavirus disease (Covid-19) outbreak situation. https://covid19.who.int/ (accessed 26 September 2020).

3) Grifoni A, Weiskopf D, Ramirez SI, Mateus J, Dan JM, Moderbacher CR. Targets of $T$ Cell Responses to SARS-CoV-2 Coronavirus in Humans with Covid-19 Disease and Unexposed Individuals. Cell 2020; 181(7):1489-01.

4) Cao H, Ruan L, Liu J, Liao W. The clinical characteristic of eight patients of Covid-19 with positive RT-PCR test after discharge. J Med Virol 2020; 92(10):2159-64.

5) Hoang VT, Dao TL, Gautret P. Recurrence of positive SARS-CoV-2 in patients recovered from COVID-19. J Med Virol 2020; 92(11):2366-2367.

6) World Health Organization. Real-Time RT-PCR Panel for Detection 2019-Novel Coronavirus 2020. https://www.who.int/docs/defaultsource/coronaviruse/uscdcrt-pcr-panel-for-detectioninstructions.pdf? sfvrsn =3aa 07934_2.

7) Wang Y, Wang Y, Chen Y, Qin Q. Unique epidemiological and clinical features of the emerging 2019 novel coronavirus pneumonia (Covid-19) implicate special control measures. J Med Virol 2020; 92(6):568-76

8) Kang $\mathrm{H}$, Wang $\mathrm{Y}$, Tong $\mathrm{Z}$, Liu $\mathrm{X}$. Retest positive for SARS CoV-2 RNA of "recovered" patients with Covid-19: Persistence, sampling issues, or reinfection? J Med Virol 2020; 92(11):2263-65.
9) Xiao AT, Tong YX, Zhang S. False-negative of RT-PCR and prolonged nucleic acid conversion in Covid-19: Rather than recurrence. J Med Virol 2020; 92(10):1755-56.

10) Chen $D, X u$ W, Lei $Z$, et al. Recurrence of positive SARS-CoV-2 RNA in Covid-19: A case report. Int J Infect Dis 2020; 93:297-299.

11) Ye G, Pan Z, Pan $Y$, et al. Clinical characteristics of severe acute respiratory syndrome coronavirus 2 reactivation. J Infect 2020; 80(5):e14e17.

12) Long $Q$, Liu B, Deng $H$. et al. Antibody responses to SARS-CoV-2 in patients with Covid-19. Nat Med 2020; 26:845-48.

13) Lin YC, Cheng CY, Chen CP. et al. A case of transient existence of SARS- CoV-2 RNA in the respiratory tract with the absence of anti-SARS-CoV-2 antibody response. Int $\mathrm{J}$ Infect Dis 2020; 96:464-66.

14) Lan L, Xu D, Ye G, et al. Positive RT-PCR Test Results in Patients Recovered from Covid-19. JAMA 2020; 323(15):1502-03.

15) Loconsole D, Passerini F, Palmieri VO, et al. Recurrence of Covid-19 after recovery: a case report from Italy. Infection 2020; 48(6):965-967.

16) Rothe $C$, Schunk $M$, Sothmann $P$, et al. Transmission of 2019-nCoV Infection from an Asymptomatic Contact in Germany. N Engl J Med 2020; 382(10):970-71.

17) Xie $X$, Zhong $Z$, Zhao $W$, et al. Chest $C T$ for typical 2019-nCoV pneumonia: relationship to negative RT-PCR testing. Radiology 2020; 296(2): E41-E45. 